\title{
MEMBANGUN RELASI UMAT BERAGAMA PASCA KONFLIK AGAMA DI TANJUNGBALAI
}

\author{
Fitriani, Indra Harahap dan Titah Utari \\ Universitas Islam Negeri Sumatera Utara (UINSU) Medan \\ fitriani@uinsu.ac.id, indrahrp80@yahoo.com,titah_utari@yahoo.com
}

\begin{abstract}
Abstrak
Agar terciptanya relasi antar umat beragama yang di landasi toleransi maka sangat penting mengintensifkan dialog antar umat beragama. Sebab dialog merupakan resolusi yang tepat dalam membangun perdamaian antar umat beragama. Hasil penelitian yang ditemukan dalam tulisan ini terkait pasca konflik yang terjadi di Kota Tanjungbalai merupakan jembatan dalam menciptakan kerukunan dengan menumbuhkan sikap toleransi, rasa peduli terhadap sesama dan meningkatkan solidaritas antar sesama masyarakat di Tanjungbalai. Penelitian ini merupakan penelitian lapangan (field research). Penelitian ini menekankan pada fungsi teori sebagai alat untuk mempertajam kepekaan peneliti dalam melihat konflik agama di Tanjungbalai dan merumuskan teori segitiga konflik Johan Galtung (peace keeping, peace making dan peace building) sebagai sarana membangun relasi yang baik pasca terlibat konflik. Tujuan penelitian ini berupaya membangun relasi antar umat beragama masyarakat Tanjungbalai yaitu dengan menghilangkan truth claim (Klaim Kebenaran) terhadap suatu agama, rasa curiga dan berupaya bersikap inklusif dalam beragama. Dengan upaya ini diharapkan terciptanya relasi atau hubungan yang harmonis antar umat beragama pasca konflik Pembakaran Vihara di Tanjungbalai.
\end{abstract}

Kata kunci: Relasi, Umat Beragama dan Pasca Konflik

\section{Abstract}

In order to create relations between religious communities on the basis of tolerance, it is very important to intensify dialogue between religious communities. Because dialogue is an appropriate resolution in building peace between religious communities. The research results found in this paper related to the post conflict that occurred in Tanjungbalai City is a bridge in creating harmony by fostering tolerance, caring for others and increasing solidarity among fellow communities in Tanjungbalai. This research is a field research. This research emphasizes the function of theory as a tool to sharpen the sensitivity of researchers in seeing religious conflicts in Tanjungbalai and formulating Joban Galtung's conflict triangle theory (peace keeping, peace making and peace building) as a means of building good relations after conflict. The purpose of this study is to build relationships between religious communities in the Tanjungbalai community by removing the truth claim of a religion, feeling suspicious and trying to be inclusive in religion. With this effort, it is expected that a harmonious relationship between religious communities will be created after the Burning of the Vihara in Tanjungbalai.

Keywords: Relationships, Religious People and Post-Conflict

\section{Pendahuluan}

Di Indonesia, adanya hubungan komunikasi sosial-keagamaan yang tampak relatif eksklusif acapkali menyebabkan konflik. Seperti halnya konflik yang terjadi di Ambon, Kalimantan, Poso dan Sampang hingga Aceh merupakan bagian konflik berlanjutan yang 
disebabkan adanya pola hubungan komunikasi sosial-keagamaan yang tertutup (H. Sudarto, 2001: 9). Sehingga (religion conflict) atau konflik agama menjadi sesuatu yang tampak normal terjadi dalam kehidupan masyarakat multikultural di Indonesia.

Berbagai macam keberagaman yang ada di Indonesia menunjukkan dengan sangat jelas pula berbagai macam karakteristik yang ada pada masyarakat. Keberagaman itu juga ada pada Kota Tanjungbalai, hal itu ditandai dengan adanya keberagaman etnik, budaya, agama, dan sebagainya. Dengan begitu banyak karakteristik yang ada pada masyarakat tentu tidak bisa pula dijauhkan dengan perbedaan kepentingan yang ada di masyarakat. Sehingga bisa saja menimbulkan berbagai macam kesenjangan yang terjadi di masyarakat. Namun acap kali kesenjangan sosial yang ada di masyarakat berakhir dengan kerusuhan. Tidak hanya itu, juga yang menjadi sasaran pada kerusuhan itu berupa pengrusakan sarana dan pra sarana yang ada di sekitarnya. Tindakan itu dilakukan secara berkelompok. Hal itu didasari terjadi karena perbedaan kepercayaan, budaya, dan ideologi yang dianut masing-masing masyarakat tersebut (J.Dwi Narwoko dan Bagong Suyanto, 2005:68). Adanya perbedaan tersebut maka terciptalah jarak dan pembatas yang menyebabkan tidak terjadinya hubungan sosial yang harmonis (H.M Darwis, 2013: 39).

\section{Metodologi Penelitian}

Penelitian ini merupakan (field research) yakni penelitian lapangan. Deddy Mulyana dan Solatun (207: 4). Kartono menyatakan bahwa penelitian lapangan hakekatnya adalah sebuah metode penelitian agar memahami secara khusus mengenai realitas yang terjadi ditengah masyarakat (Kartini Kartono, 1990: 32). Penelitian ini mengambil paradigma kualitatif yang menekankan fungsi teori sebagai media untuk mempertajam kepekaan peneliti dalam memahami konflik agama di Tanjungbalai dan merumuskan teori segitiga konflik Johan Galtung, Pertama, peace keeping yaitu suatu upaya proses mengurangi atau menghentikan aksi kekerasan melalui peran intervensi penjaga perdamaian yang netral yakni militer. Kedua, peace making yaitu upaya proses yang bertujuan merekonsiliasi pihak bertikai dengan melakukan mediasi, negosiasi, arbitrasi guna mendapat penyelesaian dengan cara damai. Ketiga, peace building yaitu proses implementasi upaya rekonruksi atau perubahan dalam konteks ekonomi, politik dan sosial untuk mencapai perdamaian yang abadi (langgeng). Dengan proses peacebuilding maka negative peace atau (the absence of violence) diharapkan berubah dan mencapai positive peace, dalam artian masyarakat merasakan secara nyata adanya suatu kesejahteraan ekonomi, keadilan sosial dan keterwakilan politik yang efektif. Teori konflik Galtung ini dijadikan sarana dalam proses resolusi konflik yang akan dibangun oleh masyarakat Tanjungbalai dalam menciptakan relasi yang harmonis pasca terjadinya konflik. (Yulius Hermawan, 2007: 93). Tujuan penelitian ini berupaya membangun 
relasi antar umat beragama masyarakat Tanjungbalai yaitu dengan menghilangkan truth claim (Klaim Kebenaran) terhadap suatu agama, rasa curiga dan berupaya bersikap inklusif dalam beragama. Hakekatnya, dengan metode penulisan ini dapat menemukan dan menyimpulkan secara detail juga khusus mengenai realitas ditengah masyarakat yang terjadi. Adapun teknik analisis dalam tulisan ini yakni dengan menggunakan metode deskriptif analisis yaitu mendeskripsikan serta menganalisis suatu permasalahan yang akan dikaji. (SuharsimiArikunto, 1985: 45).

\section{Pemicu Konflik Antar Agama di Tanjungbalai}

Konflik antar pemeluk agama dalam beberapa kasus yang terjadi terakhir ini dianggap sebagai konflik agama secara teologis. Sementara pada hakikat dan realitanya, secara umum konflik antar pemeluk agama terjadi dipicu oleh berbagai masalah, seperti : intoleransi, kemiskinan, kesenjangan ekonomi, kesenjangan sosial, kegagalan pembangunan dan sebagainya. Konflik antar pemeluk agama juga tak dapat dipungkiri hadir disebabkan oleh adanya perseteruan, baik secara individu maupun kelompok, masyarakat atau organisasi masyarakat tertentu. Lantas konflik antar pemeluk agama tersebutpun menimbulkan patologis sosial yang menyebabkan masyarakat merasa resah dan tidak nyaman. Lebih lanjut menurut Arifinsyah, konflik antar pemeluk agama adalah patologis sosial yang disebabkan oleh kegagalan sosial, pembangunan, politik, ekonomi, dan lain-lain. Kemudian agama dijadikan alat legitimasi sehingga ketika agama diklaim sebagai sumber konflik dalam masyarakat maka masyarakat meyakini bahwa ajaran teologis yang berbeda pun diduga dan dinyatakan sebagai sumber utama sumber konflik dan perpecahan. Pada hakikatnya tak satupun agama menganjurkan penganutnya agar saling berselisih dan saling berseteru dengan penganut agama yang berbeda. Hanya saja tidak bisa dipungkiri segelintir kelompok penganut agama ikut terlibat di dalamnya yang menjadi provokator dan mengatasnamakan agama untuk menciptakan disintegrasi sosial masyarakat (Arifinsyah, 2018: 84).

Secara umum terjadinya tindak pidana kerusuhan dan pengrusakan disebabkan berbagai hal, seperti motif sosial, disebabkan adanya sikap yang saling kurang menghormati dan menghargai antar sesama masyarakat yang hadir dengan latar belakang sosial yang berbeda dan bervariasi, sehingga menimbulkan kepentingan, perbedaan, yang mengakibatkan terganggunya ketentraman masyarakat. Ekonomipun juga menjadi salah satu motif penyebabnya, hal ini dikarenakan masyarakat dalam kehidupan sehari-haribya nemiliki perbedaan kemampuan, sehingga memicu terjadinya gesekan kepentingan dalam mendayagunakan sumber daya ekonomi 
dan dapat menjadikan hal tersebut terciptanya keretakan hubungan dalam masyarakat (Setyo Sumarno, 2014: 2).

Amin Abdullah dan Burhanuddin menyatakan bahwa terkadang faktor utama timbulnya kerusuhan itu bukan disebabkan oleh persoalan agama semata, akan tetapi adanya masalah lain juga memungkinkan menjadi faktor penyebab, seperti masalah sosial, ekonomi dan politik (Burhanuddin Daya dan Amin Abdullah, 2010: 24). Namun, kerusuhan bernuansa Suku, Agama dan Ras (SARA) di Provinsi Sumatera Utara, di Kota Tanjung Balai, 29 Juli 2016, merupakan bukti bahwa kekhawatiran berlanjutnya konflik keagamaan akan terus terjadi adalah benar adanya sebagai dampak negatif komunikasi yang kurang harmonis dan baik dalam hubungan sosialkeagamaan pada masyarakat. Sehingga wajar terjadi konflik anatara pemuluk agama, hingga meursak dan membakar beberapa fasilitas keagamaan seperti tempat ibadah (Gereja, Klenteng/Vihara ,Masjid dan lain-lain) dan bahkan hingga merusak bangunan lembaga sosial juga pendidikan, yang dimiliki oleh agama tertentu sering menjadi korban pelampiasan kemarahan masyarakat.

Sementara itu, peristiwa konflik Tanjungbalai dapat dinyatakan sebagai konflik yagn disebabkan oleh kurangnya toleransi kedua belah pihak yakni antara seorang dari etnis Tionghoa yang sangat mengkritik suara Adzan dari masjid dengan menyatakan bahwa suaranya terlalu keras. Hal ini sejalan dengan teori konflik Negosiasi Prinsip, yakni terjadinya konflik bermula dari keadaan-keadaan yang tidak selaras. Dalam komflik Tanjungbalai ini, ketidak selaran ataupun sikap adanya perbedaan pandangan berasal pada pihak seorang etnis Tionghoa yang beranggapan bahwa azan yang merupakan salah satu ritual keagamaan umat Islam itu menggangu umat non Muslim, lantas dari pihak umat Islam menyatakan protes nyata yang dilayangkan terhadap pihak etnis Tionghoa yang berjenis kelamin perempuan tersebut sebagai penistaan terhadap agama Islam.

\section{Resolusi Konflik Pembakaran Vihara di Tanjungbalai}

Menyikapi konflik pembakaran Vihara di Tanjung Balai tersebut dan sebagai upaya pencegahan terjadinya kasus yang senada, maka warga Tanjungbalai khususnya yang mengalami perpecahan akibat adanya segregasi agama, tempat tinggal, sosial ekonomi, suku, pekerjaan, etnik, harus memperhatikan beberapa reslusikonflik di bawah ini, diantaranya:

Pertama, memecahkan, mengentaskan dan mengatasi akar problematka yang menjadi sebab utama terjadi konflik di Tanjungbalai. Seperti halnya permasalahan kesenjangan sosial ekonomi yang harus diaatasi dengan hadirnya suatu kebijakan yang memberi affirmative action dan special treatment terhadap mereka ekonomi lemah dari kaum pribumi. Sebagaimana juga pernah 
terjadi di Negara Malaysia, melalui (NEP) New Economic Policy mereka berhasil dan mampu bahkan sukse mengurangi adanya kesenjangan sosial ekonomi antara etnik Cina dan Melayu.

Kedua, membentuk suatu wadah sebagai forum komunikasi dan dialog antara kelompok yang berbeda stratifikasinya, baik dari segi suku, tempat tinggal, etnik, sosial ekonomi dan sebagainya. Lantas jika terjadi masalah-masalah baru dan perbedaan sikap dapat dilakukan komunikasi yang baik dan terbuka demi menghasilkan solusi dan resolusi terbaik tanpa harus dengan sikap kekerasan dan pembakaran.

Ketiga, untuk menenangkan ketegangan sosial yang terjadi yang disebabkan adanya kesenjangan sosial ekonomi antara kaum pribumi dan etnik Tionghoa, maka peran pemerintah sangat diharapkan mampu memberi prioritas utama terhadap kaum muslim dari sisi pendidikan, dengan menyediakan dan memfasilitasi serta mempermudah beasiswa penuh melanjutkan pendidikan baik dalam maupun luar negeri. Program tersebut pasti akan berdampak positif dengan kemajuan kaum pribumi secara konsisten juga berkesinambungan serta menolong masyarakat mayoritas masih lemah dalam bidang ekonomi dan pendidikan serta mutlak dilakukan sebagai kegiatan berjangka panjang.

Keempat, menaruh sikap dengan skala besar dan prioritas sebagai penceahan terjadinya kembali konflik dan tidak sebatas tidak hanya di Tanjung Balai, Sumatera Utara, melainkan di seluruh daerah lainnya di Indonesia, yakni dengan mengentaskan faktor utama permasalahan yang berdampak terhadap hadirnya konflik.

\section{Upaya dalam Membangun Relasi Pasca Konflik Agama di Tanjungbalai}

Upaya membangun relasi antar umat beragama di lingkungan masyarakat Tanjung Balai melalui pendekatan persfektif agama sudah sangat sering dilakukan, bahkan jauh sebelum adanya konflik ini. Akan tetapi, oleh salah satu kelompok umat beragama hal ini diartikan lain, kelompok tersebut mwnyatakan bahwa kegiatan ini merupakan bentuk provokasi. Namun dalam hal ini, MUI cabang Tanjung Balai langsung berperan cepat dan aktif dalam upaya rekonsiliasi, MUI ikut serta berdeklarasi dan berusaha untuk mengakhiri kerusuhan. MUI cabang Tanjungbalai juga meminta massa sebagai sanksi atas adanya disintegrasi sosial di kalangan masyarakat, dengan meminta massa untuk ditarik keluar dari Tanjungbalai.

Selain pendekatan agama, masyarakat Tanjungbalai menerapkan pendekatan yang berbasis pada masyarakat lokal pada saat proses rekonsiliasi konflik Tanjungbalai. Gerakan yang menjangkau hingga pada tataran Akar rumput masyarakat ini banyak diprakarsai oleh LSM dengan tokoh masyarakat setempat, salah satunya adalah gerakan Melayu Bersatu. Gerakan Melayu Bersatu merupakan gerakan masyarakat sipil yang berperan aktif dalam upaya 
penghentian konflik Tanjungbalai. Gerakan lain yang peduli terhadap korban-korban konflik diprakarsai oleh masyarakat lokal yakni (JPA) Jaringan Pendidikan Anak.

Menciptakan perdamaian dan kenyamanan serta pemahaman di antara komunitas yang berbeda adalah sisi elemen penting kemanusiaan, maka penyelesaian konflik berperan untuk dimainkan, walau dalam zona perang sekalipun. Hugh Mail melanjutkan bahwa luasnya pemahaman penyelesaian konflik, hakikatnya tidak sebatas menyangkut mediasi antara pihakpihak yang bertikai semata, namun juga upaya dari pada aktor-aktor yang berperan dan tetap mempertahankan konflik dan kekerasan sebagai dalang dari disharmonisasi di masyarakat. (Hugh Miall, 2000: 5).

Melihat situasi dan tantangan dalam mempertahanan kehidupan yang berbangsa dan bernegara di negara yang menjunjung tinggi nilai demokratis, maka konflik yang terjadi di Kota Tanjungbalai harus dicegah dan diakhiri atau dalam arti lain tidak boleh dibiarkan terus menerus terjadi, hal tersebut pasti akan menganggu dan merusak keseimbangan tatanan masyarakat. Untuk itu Pemerintah selaku penyedia keamanan bagi negara harus bisa menjaga, melindungi, dan mengayomi masyarakatnya dengan baik. Sehingga pemerintah mempunyai tanggungjawab besar bagi kehidupan bermasyarakat untuk mencapai suatu keadilan yang sama dalam kedudukannya tanpa diskriminatif. Masyarakat juga mempunyai tanggungjawab dan kewajiban untuk negara, serta ikut dalam mewujudkan keamanan dan kenyamanan bagi seluruh masyarakat luas (SudiknoMertokusumo, 2007: 3).

\section{Relasi Masyarakat Islam dan Buddha}

Manusia yang merupakan makhluk beragama kini dalam situasi yang sangat memperihatinkan, seolah manusia bagaikan serigala bagi manusia lainnya, ini merupakan hal yang sangat naif. Dewasa ini, secara transparan, jelasa dan real dipertontonkan di berbagai penjuru terjadinya anarkisme, pengusiran, pembakaran rumah ibadah, pembunuhan terhadap orang yang beribadah, teroris dan peledakan bom menewaskan tak sedikit orang, kekerasan bagi pemuka agama, kedzaliman penguasa akan rakyatnya, penembakan imam dan pemuka agama, rasisme, laranan penggunaan hijab, larangan melaksanakn puasa dan lain sebaginya, sehingga manusia beragama tampak haus dan dahaga akan perdamaian kehidupan dunia. Mereka sudah lama merasakan bosan dengan hubungan persengketaan dalam beragama (Saidurrahman \& Arifinsyah, 2018: 5).

Sebelum ada persoalan kerusuhan yang terjadi di Tanjungbalai, interaksi antara umat muslim dengan Buddhis terjadi secara alamiah, dan dapat dinytakan bahwa hubungan MuslimBuddhis dalam bentuk hubungan antara etnis Buddhis dengan etnis Pribumi dalam keadaan 
cukup baik. Interaksi Muslim dengan Buddhis, pada umumnya bentuk interaksinya "saling ketergantungan" yakni dalam bidang mata pencarian dan ekonomi.

Islam mengajarkan tentang perlunya menjalin hubungan baik antara muslim dan non muslim, pentingnya saling menghormati, saling menghargai, dan berbuat baik kepada seluruh umat, karena islam menghimbau dalam ajarannya bahwa berbuat baik tiu tak memandang agamamu. Begitu halnya terdapat beberapa hal yang dapat dibentuk sebagai azas penyusunan konsep kerukunan dalam Islam, antara lain adalah : al-Quran merupakan teks yang sangat toleran dibaca, dpelajari, dianut dan dipedomani oleh mayoritas penduduk Indonesia yang notabennya banyak menganut agama Islam, al-Quran sanat mendukung kehidupansaling toleransi di Indonesia. Toleransi menjadi komitmen teologis bagi umat Islam. Karena bagi mereka realitas keragaman merupakan anugrah nyata Allah yang harus dijadikan sebagai potensi dalam membentuk kerja sama dengan mewujudkan rahmat kebersamaan sebagai satu bangsa dan negara. Ajaran Islam sangat mengajarkan secara tegas bertoleransi dan hal ini juga disyaratkan oleh Pancasila sebagai suatu kesepakatan dan kesepahaman bersama dalam bingkai masyarakat.

Menurut pemaparan Tan Giok Saw sebagai pemuka agama Budha menyatakan: Ajaran Buddha merupakan ajaran tentang keterbukaan pikiran dan hati yang simpati, yang menerangi dan menghangatkan segenap semesta dengan sinar ganda Kebijaksanaan dan Welas Asih, memancarkan sinar keramahan pada setiap makbluk dalam perjuangan mengurangi samudra kelabiran dan kematian.Rasa belas kasiban yang ada pada diri Sang Buddha sendiri, bila dipergunakan untuk mencintai semua makbluk yang mengalami penderitaan untuk melakukan kasihan itu, setelah melaksanakan rasa kasih sayang sebagaimana balmya ia mencintai semua manusia, inilah yang disebut Satwalambanakarma.

Dasar keyakinan agar terbentuknya suatu kerukunan umat beragama dalam agama Budha, dikikrarkan oleh salah satu raja berkeyakinan Buddha, yakni raja Asoka Wardana, yang dibuktikan dengan sebuah Prasasti Batu Kalinga No XXII, yang berbunyi:

'Janganlah kita menghormati (mazhab) sendiri dengan mencela agama orang lain tanpa sesuatu dasar yang kuat. Sebaliknya agama orang lain hendaknya dihormati atas dasar-dasar tertentu. Dengan berbuat demikian, kita telah membantu agama kita sendiri untuk berkembang disamping pula tidak. merugikan agama orang lain. Oleh karena itu kerukunanlah yang dianjurkan dengan pengertian bahwa semua orang hendaknya memperbatikan dan bersedia mendengarkan ajaran yang dianut oleb orang lain."

Dalam hal hubungan baik antara umat beragama, masyarakat Islam secara umum tidak memiliki problem dengan umat Buddha, baik dalam pandangan ke-cinaannya bagi masyarakat Islam begitu juga perlakuan kehidupan bermasyarakat sehari-hari. 
Tan Giok Saw merupakan seorang warga etnis Tionghoa mengatakan: Hubungan saya dengan tetangga yang dominan beragama Islam setempat cukup baik dan harmonis. Babkan saya dengan tetangga saya sudah seperti saudara sendiri, seringkali tetangga sesama tetangga saling mengunjungi ketika ada salah satu keluarga yang sakit. Saya mengakui bahwa diantara kami seakan tidak ada perbedaan anatara etnis Buddhis dan Pribumi, perbedaan etnis itu seakan sudah luntur dalam kegiatan kemasyarakatan.

\section{Relasi Tokoh/Lintas Agama Pasca Konflik di Tanjungbalai}

Urgensi kerukunan antar umat beragama adalah agar terciptanya relasi yang dalam setiap kehidupan masyarakat agar terjalin lebih harmonis untuk kedamaian, tolong menolong, dan tidak saling bermusuhan. Hal ini dapat terjadi karena jalinan interaksi yang ada pada perorang maupun kelompok masyarakat atas dasar status dan peran sosial. Cara menjaga sekaligus mewujudkan relasi tersebut yakni dengan berdiaolog dan berkomunikasi hubungan terbuka antar umat beragama yang yang membahas tentang relasi antar sesama umat beragama.

Hubungan ini terjadi berdasarkan kedudukan sosial maupun status sosial. Seperti, bawahan berhubungann baik dengan atasan, atau sebaliknya. Para oknum yang bersangkutan dalam pergaulan sepatutunya menaati dan menjaa sopan santun yang sesuai dengan statusnya dna keadannya.

Relasi terjadi sesuai fungsi dan peran yang masing-masing orang. Masing-masing fungsi adalah wadah pertukaran jasa dan pertemuan. Seperti halnya, seseorang dokter berperan dan berfungsi bagi pasien, seorang pembeli bertemu dengan penjual. Masing-masing pemegang peranan haruslah mengikuti pola sesuai fungisionalnya. Sudah diketahui secara umum bahwa mayoritas interaksi dan komunikasi dalam masyarakat adalah relasi yang terjadi seputar status yang tak terpisahkan akan peran dan kewajiban juga tugasnya yang secara otomatis ditangguhkan pada kedudukan itu.

Pemuka agama Islam Bapak Ustad Abdul Qodir Marpaung mengatakan:

"Manusia ditakdirkan Allah Swt sebagai makbluk sosial yang membutubkan bubungan interaksi dan sosial dengan sesama manusia. Sebagai makbluk sosial manusia memerlukan kerja sama dengan orang lain dalam memenubi kebutuhan hidupnya, baik kebutuhan material maupun spiritual. Masyarakat di Kota Tanjungbalai walaupun berbeda agama dan berbeda suka namun baik. Islam maupun Buddha dan agama-agama lain tetap saling menjalin kehidupan dan kerukunan, saling menghargai dan menghormati dan saling membantu baik dari segi ekonomi maupun bertoleransi dalam beragama saling menghargai dalam menjalankan ibadab masing-masing. Pasca insidentyang pernah terjadi di 
Tanjungbalai tabun 2016 lalu, relasi maupun bubungan antara para pemuka agama Islam maupun Buddha tetap terjalin dengan baik, tidak ada saling menyinggung tetang masa lalu tersebut".

Selain itu juga, ajaran Islam menghimbau umatnya agar hidup hidup saling bersaudara, karena hakikatnya manusia itu saudara, seperti dalam semboyan Indonesia "berbeda-beda tetapi tetap satu jua". Persaudaraan adalah salah satu ajaran yang tidak bermakna sebatas persaudaraan antara antara satu agama, atau antara umat musim saja, namun juga mengandung makna bahwa persaudaraan yang diajarkan oleh islam adalah secara umum buat seluruh makhluk hidup.

\section{Penutup}

Relasi antar umat beragama di Kota Tanjungbalai pasca terjadinya konflik yang berbau SARA yang terjadi pada tahun 2016, hingga kini baik Islam maupun Buddha menjalani kehidupan bertetangga dengan saling menghomati dan menghargai. Tanpa ada sekat yang membatasi antara islam dan buddha. Pasca konflik yang terjadi pada tahun 2016 sudah menjadi sebagai luka dan kenangan lama yang harus dilupakan. Belajar untuk menerapkan konsep "Forgive and Forget” yaitu memaafkan kesalahan orang lain dan berusaha melupakan perbuatan buruk (kesalahan) orang lain kepadanya. Dengan begitu seseorang akan dengan mudah melepaskan kepedihan dan kesakitan atas pristiwa masa lalu yang kelam sehingga rasa benci tidak pernah hadir dalam kehidupannya.

Kedua, Relasi antara para tokoh/lintas agama juga berhubungan dengan baik, saling menghargai dan saling menghormati, tidak membedakan agama maupun suku manapun. Sebab dalam ajaran agama juga menyebutkan yang membedakan manusia dengan manusia lainnya adalah ketaqwaannya bukan suku atau agamanya. Sebagai makhluk sosial yang membutuhkan hubungan interaksi dan sosial dengan sesama manusia, baik dari kebutuhan material maupun spiritual. Masyarakat di Kota Tanjungbalai walaupun berbeda agama dan berbeda suku namun baik Islam maupun Buddha dan agama-agama lain tetap saling menjalin kehidupan dan kerukunan, saling menghargai dan menghormati dan saling membantu baik dari segi ekonomi maupun bertoleransi dalam beragama saling menghargai dalam menjalankan ibadah masingmasing. Sehingga relasi antar umat beragama di Tanjungbalai bisa terjalin denngan baik dan harmonis. Penelitian ini diharapkan agar umat beragama di Tanjungbalai mengambil ikhtibar (pelajaran) atas peristiwa konflik tersebut agar lebih menghargai dan menghormati antar sesama, bersikap inklusif dalam beragama dan mampu menontrol emosi serta tak mudah terprovokasi perkataan yang berniat memecah belah kerukunan umat beragama. 


\section{Daftar Pustaka}

Arikunto, Suharsimi,. (1985). MetodologiPenelitianKualitatif. Bandung: RinekaCipta.

Daya, Burhanuddin dan Amin Abdullah. (2010). Kuliah Umum Dialog Lintas Agama dan Budaya. Yogyakarta: Prodi Agama dan Filsafat UIN Sunan Kalijaga.

Habib, Achmad,. (2004). Konflik Antar Etnik di Pedesaan: Pasang Surut Hubungan Cina-Jawa. Yogyakarta: LKIS.

Hendropuspito, D. (1983). Sosiologi Agama. Yogyakarta: Kanisius.

Herimanto dan Winarno. (2014). Ilmu Sosial dan Budaya Dasar. Jakarta: Bumi Aksara.

Hugh Miall. (2000). Resolusi Damai Konflik Kontemporer: Menyelesaikan, Mencegab, Melola dan Mengubah Konflik Bersumber Politik, Sosial, Agama dan Ras. Jakarta: PT RajaGrafindo Persada.

K. Garna, Judistira. (1992). Teori-teori Perubahan Sosial. Bandung: Program Pascasarjana Padjajaran. Kartono, Kartini. (1990). Pengantar Metodologi Riset Sosial, Bandung: Mandar Maju.

Madjid, Nurcholis. (1999). Islam Doktrin dan Peradaban. Jakarta Selatan: Pramadina.

Mizuno, Kogen dan Litt. D. (1989). Primitive Buddhism, Jepang: Kosei Publishing Company.

Muhadjir, Noeng. (1989). Metodologi Penelitian Kualitatif. Jakarta: Gramedia.

Mulyana, Deddy dan Solatun. (2007). Metode Penelitian Komunikasi: Contoh-Contoh Penelitian Kualitatif dengan Pendekatan Kritis. Bandung: PT Remaja Rosdakarya.

Munawar, Budhy dan Rahmat. (2007). Islam dan Pluralisme. Jakarta: Paramadika.

Rahmad, Jalaluddin. (1984). Metode Penelitian Komunikasi Dilengkapi Contoh Analisis Statistik. Bandung: Remaja Rosdakarya.

Ritzer, George. (1992). Sosiologi Ilmu Pengetahuan Berparadigma Ganda. Jakarta. Rajawali Pers.

Saidurrahman, Arifinsyah. (2018). Nalar Kerukunan (Merawat Keragaman Bangsa Mengawal NKRI). Medan: Perdana Publishing.

Syafuan Rozi, dkk. (2006). Kekerasan Komunal: Anatomi dan Resolusi Konflik di Indonesia. Yogyakarta: Pustaka Pelajar.

Yulius Hermawan. (2007). Transformasi dalam Studi Hubungan Internasional: Aktor, Isu dan Metodologi. Yogyakarta: Graha Ilmu. 